\title{
Money, income, and profit: lessons from the monetary theory of production
}

\author{
Andrea CARRERA \\ University of Lugano \\ andrea.carrera@usi.ch \\ Sergio ROSSI* \\ University of Fribourg \\ sergio.rossi@unifr.ch
}

Received: 29/06/2015

Accepted: 13/07/2015

\begin{abstract}
In this paper we analyze Augusto Graziani's numerous contributions to the monetary theory of production, which he developed from a theoretical but also a policy-oriented perspective. We focus on the rejection of the neoclassical dichotomy, the causal relation between production and money creation, and the definition of macroeconomic saving. These three dimensions of Graziani's work can be identified in the framework of the monetary circuit, in the tradition of classical and Marxian economic thought. The outcome of Graziani's investigations sheds light on the working of a monetary economy of production from the issuance of bank money to the distribution of income and capital accumulation.
\end{abstract}

Keywords

Keynesian theories, theories of the monetary circuit, investment

JEL classification: E12; E22; E23

Contents: 1. Introduction. 2. The neoclassical dichotomy: a long road to its rejection. 3. Production and money creation: a causal relation. 4. Saving and profit: new insights. 5. Conclusion

\section{Introduction}

Augusto Graziani - as Lavoie (2004, p. 136) pointed out - was the Italian exponent of the theory of the monetary circuit (TMC), which had been developed in France since the early 1960s, notably by authors like Alain Parguez, François Poulon, and Bernard Schmitt. However, Graziani himself noted (2003, p. 4) that Paolo Sylos Labini must be cited as an Italian precursor of the idea, supported by most theorists of the monetary circuit, that money is endogenously determined 'by the banks in response to the demand for credit from firms'. In the Anglo-Saxon world, on the other hand, 'approaches very similar in content to the circuit approach' (Graziani, ibid.) can be found in the writings of Keynes, Joan Robinson, Dillard, Godley, Wray, and Eboli.

The process of endogenous money creation (see for instance Sylos Labini, 1948; Godley, 2004, p. 127; Rochon and Rossi, 2013) is closely connected to what Arestis (2004, p. 373) identifies as the 'central theme' of Graziani's monetary theory, namely, 'the power of producers', which 'is located in their ability to have access to bank credit and financial markets'. Indeed, banks create money according to the production plans of firms, because 'circuit theorists usually assume that only firms are admitted to bank credit' (Graziani, 2003, p. 27). In this perspective, then, 'the role of financial markets is not one of collecting savings in order to finance investment, but rather one of making it possible for firms to repay their bank debts' (Graziani, 1992, p. 218, cited in Lavoie, 2004, p. 138). The main contribution of Graziani's (1983, 1984, 1989, $1994,2003)$ monetary theory is indeed his analysis of the process of money creation and destruction, money being identified with the bank money used to pay out wages necessary to purchase production. Graziani contributed to developing a theory that integrates money and pro-

\footnotetext{
* An earlier version of this paper was presented at the 41st annual meeting of the Eastern Economic Association, held in New York City on 26 February-1st March 2015. The authors are grateful to Simona Cain for improving the English style of this paper and to two anonymous referees for their constructive comments. The usual disclaimer applies.
} 
duction, shedding new light on the 'monetary theory of production' (MTP), the theme - and title - of Keynes's lectures at King's College in Cambridge since 1932, his 1933 article in honour of Spiethoff, and the first draft of his (1936) General Theory of Employment, Interest and Money (see Moggridge, 1992; Fontana and Realfonzo, 2005). The MTP approach is not based on neoclassical microeconomics, since 'in the perspective of this approach, macroeconomic analysis cannot be derived from microeconomic foundation through aggregation' (Arena and Salvadori, 2004, p. xiii): single companies are agents of a macroeconomic nature, because their economic activity is the source of value within the economic system considered as a whole.

In this paper, we analyse Graziani's specific contributions to the MTP, which he developed at both the theoretical and policy-oriented level. We will look at three particular elements: the rejection of the neoclassical dichotomy (section 2), the causal relation between production and money creation (section 3), and the definition of macroeconomic saving (section 4).

\section{The neoclassical dichotomy: a long road to its rejection}

Graziani's monetary theory of production is built on the analysis of a pure credit economy, as other theories of the monetary circuit are (see Schmitt, 1972, 1975, 1984; Parguez, 1975, 1996, 2001). According to Graziani, three categories of participants interact in an economic system: wage earners (also called workers or households), firms (also called capitalists, entrepreneurs or shareholders), and a single bank, which 'may be a private bank, set up by some private entrepreneurs, or it may be an institution set up by the State' (Lavoie, 2003, p. 506). One of Graziani's merits is to have emphasized the intermediary role of banks between firms and households, which led him to identify two sets of agents only: 'producers', who 'have access to bank credit', and 'wage earners', who 'can only spend already-earned income' (Graziani, 2003, pp. 25-26). In this framework, there are no reserve assets, and the government has no budgetary role: taxes and public expenditure play no part in the Graziani monetary circuit. For the sake of simplicity, foreign transactions and exchange rates are assumed not to exist. In order to achieve the goals of their business plans, firms 'as a whole only need money to hire labour by paying the wage bill' (Parguez, 2004, p. 257).

The modern monetary theory of production is founded on the rejection of the neoclassical dichotomy between real and nominal magnitudes. Specifically, the merit of the MTP is to having shed light on the non-physical nature of bank money. However, as we will briefly observe in this section, it has taken a relatively long time to build a unitary theory of real and monetary production: the concept of money as a token was first grasped by classical economists, rejected by neoclassical theory, and then brought back into economic literature by Keynes and his followers.

\subsection{Money as a token: the insights of classical economics}

Being issued by banks, money is a token, created 'at the stroke of the pen' (Lavoie, 2003, p. 507) in the banks' books, as the numerical tool of a pure credit economy. Being issued 'by means of negotiations between banks and firms', money is thus endogenously determined (Graziani, 2003, pp. 25-26). Graziani (2003, pp. 25-26) is indeed well aware of the fact that money is not a simple means of exchange of commodities, but the tool for determining 'the division of production between consumption and investment goods': money is therefore needed to analyse the 'distribution of income between wages and profits'.

The intuition that money does not share the characteristics of any physical commodity dates back to classical economists (see Cencini, 2001; Graziani, 2003). Furthermore, the concept of income as the integration between money and production explained by the theory of the monetary circuit is not entirely new in the history of economic thought.

In Adam Smith (1777 [1981]), money, though often been seen as a commodity, even by classical authors, received special attention with respect to commodities in general. For example, Smith explains that money, or 'the great wheel of circulation', is 'altogether different from the goods which are circulated by means of it' (Smith, 1777 [1981], p. 289). Also, Smith is aware that the concept of money is to be distinguished from the concept of income: it is the real content of money to be turned into income, owing to the homogenising role of money. Smith (1777 [1981], p. 289) argues that '[t]he revenue of the society consists altogether in those goods, and 
not in the wheel which circulates them'. Without money, however, these goods would retain their physical nature and could not be transformed into economic goods.

Smith observes that the term 'money' does not necessarily mean the metal with which it is identified, but rather the production that is associated with it. In his view, it is not possible to talk about the value of money and the value of wealth or income associated with money and count that value twice. In this regard, Smith explains that

[w]hen, by any particular sum of money, we mean not only to express the amount of the metal pieces of which it is composed, but to include in its signification some obscure reference to the goods which can be had in exchange for them, the wealth or revenue which it in this case denotes, is equal only to one of the two values which are thus intimated somewhat ambiguously by the same word, and to the latter more properly than to the former, to the money's worth more properly than to the money (Smith, 1777 [1981], p. 290).

In the passage quoted above, from the Wealth of Nations, Smith hits an obstacle (double counting a given value), which the theory of the monetary circuit has solved by asserting that money has no intrinsic value, and that value is formed only when money and production are blended in the form of income, when wages are paid out. Money cannot be identified with the income of a country unless it is associated with some production. Smith understands that money alone 'makes no part of the revenue of the society to which it belongs' (Smith, 1777 [1981], p. 291), and that 'though the wages of the workman are commonly paid to him in money, his real revenue, like that of all other men, consists, not in the money, [...] not in the metal pieces, but in what can be got for them' (Smith, 1777 [1981], p. 295).

Ricardo (see Sraffa and Dobb, 1951-1973) realized that there was a strong relationship between money and production; therefore, as Adam Smith had done before him, he introduced in his study both real variables and nominal variables. In particular, Ricardo identified the value of real production with its monetary costs, and this made him the first economist to distinguish between 'physical production (transformation) of values in use and economic production of value' (Cencini, 1985a, p. 108, our translation). Here is, therefore, a first cautious rejection of the conception of value as a substance, a distancing that was to be seen more clearly in Marx. It is indeed in Marx that one finds 'the premises of the rejection of that concept of value-substance that had already created so much trouble to Ricardo. Thought of as a form of value, [...] money expresses the social value of the product with which it is identified' (Cencini, 1985a, p. 109, our translation).

The history of economic thought of the early twentieth century is well known: adhering to the 'marginalist revolution', the majority of economists abandoned any attempt to study the particular characteristics of money, and so failed to integrate the latter into a theory of production. In fact, most macroeconomic theorists paid remarkable attention to equilibrium models à la Hicks.

\subsection{The neoclassical conception of money as an asset: a rejection}

As observed by Arena and Salvadori (2004, p. xv) in their collected Essays in Honour of Augusto Graziani, 'Graziani rejects the simultaneous treatment of stocks and flows as it appears in some macroeconomic models of the IS/LM type'. In fact, Graziani argues that

[t]he IS-LM model is rejected by circuit theorists on the ground that, by considering the money stock as a given magnitude, it omits the analysis of the creation of money, neglects the relationships between banks and firms (in the Hicks-Hansen model, banks and firms are in fact aggregated into one single sector), and consequently ignores the interdependence between the IS and the LM lines (Graziani, 2003, pp. 22-23).

Graziani (2003) is well aware of the fact that, by conceiving of money as a physical asset, neoclassical authors fail to integrate money into the production process. On the one hand, as Graziani (2003, p. 148) puts it, in a perfectly competitive equilibrium along neoclassical lines, 'profits should disappear. In a competitive market, an entrepreneur should operate without profits or losses and his remuneration should be viewed as a reward for the work performed as a co- 
ordinator of production'. However, Graziani and other circuitists have shown that profit does exist and is indeed distinct from the remuneration of shareholders (unless distributed as dividends). As noted by Parguez (2004, p. 268), '[p]rofits do exist in the pure capitalist economy and they are "endogenous" relative to firms' accumulation plans which create them'. In fact, when profits are invested for the accumulation of capital, capital goods have a value that is net (see, for instance, Parguez, 1975; Schmitt, 1984; Cencini, 2001; Graziani, 2003; Rossi, 2007; Carrera, 2014). On the other hand, the neoclassical definition of money as an asset implies that price determination is necessarily in relative terms: any two physically heterogeneous goods are supposedly made homogeneous after they enter into an exchange relation. However, this hardly furthers the cause of the theory of value, which according to Bellofiore $(2004$, p. 90) 'is not merely aimed at discovering the laws governing the long-period, or equilibrium, relative prices': as the author explains, '[a]ll commodities are a frozen quota of [...] labour spent by the overall labour force of the society' (Bellofiore, 2004, p. 90). The value of production is indeed numerically expressed by wages. In other words, money and production are linked to each other in an absolute exchange: physical products and services are instantaneously changed into income, which is expressed in wage units (see for instance Cencini, 2001). Therefore, any commodities 'are value before any specific actual exchange relation with other commodities is set up' (Bellofiore, 2004, p. 90). The neoclassical theory of price determination thus breaks down, because in this framework 'the monetary movements are totally subordinated to the real movements, the demand for, and supply of, money being possible only through the supply of and demand for goods' (Cencini, 1985a, p. 110, our translation). Hence, if money is considered an integral part of the set of commodities, "the only determination that we can hope to achieve is that of relative prices, while, if it is considered external to it, it becomes possible to define the absolute (monetary) price of each commodity' (Cencini, 1985a, p. 111, our translation).

Therefore, as Solow (2000, p. 378) points out, no explanation of price determination can be found in the Walrasian theory of economic growth. Further, Graziani and other theorists of the monetary circuit have shown that the general equilibrium theory, based on the perfect competition assumption, fails to develop a monetary theory respective of the macroeconomic laws governing our modern economies. New answers to the study of production in real and nominal terms are therefore to be found in another historical tradition, based on imperfect market competition (see Sylos Labini, 2005, p. 45): this tradition consists in the theories of income distribution in the wake of Keynes's (1936) work.

\subsection{The monetary theory of production since Keynes}

Keynes's broad goal in The General Theory was to take a step back from classical theory. ${ }^{1}$ Specifically, Keynes rejected the hypothesis of the 'special case assumed by the classical theory', since its characteristics 'happen not to be those of the economic society in which we actually live' (Keynes, 1936, p. 3). As a matter of fact, the possibility of 'involuntary' unemployment is not admitted by the classical theory (Keynes, 1936, p. 6), as if, following Keynes's example (1936, p. 9), 'unemployment in the United States in 1932 was due either to labour obstinately refusing to accept a reduction of money-wages or to its obstinately demanding a real wage beyond what the productivity of the economic machine was capable of furnishing'. This remark still holds true today, during the economic turmoil affecting the beginning of the twenty-first century. Before undertaking an analysis of unemployment, a monetary theory of production was needed. This is why, in The General Theory, Keynes aims to dispose of the 'neoclassical dichotomy', seeking to reconcile the real and the monetary dimensions of production. Overcoming that dichotomy is indeed a necessary step in the process of value and price determination, which remains one of the most controversial issues in economic analysis (see Pasinetti, 1989). In sharing Keynes's plan, Graziani is perfectly aware of the 'great plausibility', remarked by Keynes (1936, p. 20), 'that the costs of output are always covered in the aggregate by the saleproceeds resulting from demand', having 'the income derived in the aggregate by all the ele-

\footnotetext{
${ }^{1}$ Making use of the adjective classical, Keynes (1936, p. 3) explicitly refers to 'a name invented by Marx to cover Ricardo and James Mill and their predecessors', but also to 'the followers of Ricardo': J.S. Mill, Marshall, Edgeworth and Pigou, that is, neoclassical authors.
} 
ments in the community concerned in a productive activity necessarily [...] a value exactly equal to the value of the output.'

Following this line of inquiry, Keynes's 1936 work, as well as Graziani's and circuit theories, can be interpreted as the revival of the classical concept of the determination of absolute prices. The identity between real and nominal production was first detected by Keynes, and it clearly represents the rejection of the dichotomy between nominal (money) and real (commodities and services) magnitudes. However, as observed by Graziani (1983), Keynes's work has often been seen as the study of economic recessions, and not, as it should, as a unitary analysis of both money and production. This is why, as Moore $(2004$, p. 239) points out, modern authors of the MTP have searched for an 'alternative approach' to monetary issues as a result of the dissatisfaction with Keynes's (1936) 'neglect' of banks as fundamental institutions in 'the financing of production', and consequently in the determination of investment.

The framework of the monetary circuit was taken up and developed within the MTP by economists in the wake of Keynes's Treatise on Money (1930) as well as The General Theory (1936). This is why the TMC can also be used to refer to the MTP. We are indebted to Graziani for his attempt to explain the similarities between the two theories that have been developed in the decades following Keynes's 1936 work by post-Keynesian authors as well as by monetary circuit theorists.

\subsection{The theory of the monetary circuit and Keynes's conception(s) of money}

To understand the similarities between Graziani's and Keynes's conceptions of money, one needs to consider Keynes's different ideas on the function(s) of money. As Graziani (1996) noticed, in The General Theory money is defined as a stock of wealth. In that book, money, as the liquid form of wealth (cash balances), can originate a lack of aggregate demand when it is preferred to real capital goods. However, Graziani (1996) evokes another conception of money, which, according to him, is to be found in Keynes's writings before and after The General Theory, namely, money as being endowed with purchasing power. This alternative conception of money is the starting point of the theories of the monetary circuit, including Graziani's, according to which money is the numerical unit of account of produced output. 'If money is defined as purchasing power, it only covers what is actually used as a means of payment, namely legal tender and bank deposits' (Graziani, 1996, p. 141). In this view, The General Theory is therefore a book separate from the other works of Keynes. This does not come as a surprise in economic literature. It is indeed well known that, ever since 1936, the economics profession has been debating on the continuity versus the novelty of Keynes's economic thought, in particular regarding the years between the publication of the Treatise on Money (Keynes, 1930) and The General Theory (see for instance Garegnani, 1979; Pasinetti, 1986; Lunghini, 1988). There is a large consensus among economists that, after publishing The General Theory, Keynes broke up with tradition: for instance, Pasinetti (2007) considers that there has been a (1936) Keynesian 'revolution'. However, Keynes's economic thinking evolved considerably over different periods. Graziani (1996) notably divides Keynes's thought into three periods: in the first period (up to 1930), he conceives money as exogenous to the economic system, and as having a purchasing power per se; in the second period (1931-36), according to Keynes, money, still an exogenous magnitude, plays in particular the role of a stock of wealth; in the third period (after 1936), Keynes considers money as an endogenously-determined magnitude, and endowed with purchasing power. Graziani's theory is akin to the third Keynes's period, when 'Keynes had in mind a sort of complete model, in which the money stock no longer comes from outside, but banks are included among the agents, and money is regularly created according to the financial needs of production' (Graziani, 1996, p. 147). Deleplace and Nell (1996) clarify and further elaborate on these concepts. By studying the institutional foundations of economic systems, rather than their supposed 'micro foundations' typical of neoclassical and new-Keynesian theories, it becomes possible to grasp economic reality: the production process is carried out thanks to the operative activity of firms, the labour supplied by households, and the lending activity of the banking system. Money is thereby a magnitude that is endogenously determined by the banking system as a direct result of production activities. This theoretical framework represents the successful completion of Keynes's attempt, since The General Theory, to blend the investi- 
gation of real economies with the analysis of banking systems, thus developing a monetary theory of production. It must also be noted that this approach - epitomised by the theories of the monetary circuit - is unique in the history of economic thought after Keynes. According to Davidson (2003-2004), in fact, a number of Keynesian economists neglected the role of money in modern economic systems, because they studied Keynes's economic thinking from the viewpoint of the so-called neoclassical synthesis (see for instance Hicks, 1937; Modigliani, 1944). In this regard, Smithin (1994, p. 64) remarked that circuitists (see also Lavoie, 1992, p. 444) and post-Keynesian authors have consistently challenged the quantity theory of money, thereby rejecting the neoclassical association of money to a physical asset, as if (bank) money shared the same characteristics of any other commodity. Indeed, the neoclassical postulate of money neutrality is firmly rejected by the circuitist approach (see Smithin, 2013). Hicks himself '(1967, $1982,1989),[\ldots]$ put forward a view of money very different from that in the same author's famous contributions of the 1930s cited above' (Smithin, 1994, p. 18). Graziani played an essential role in determining the relation between bank money and production, thereby disposing of the 'neoclassical dichotomy'. As the next section shows, Graziani's investigation of money circulation prompted the attention of circuitists in the so-called Dijon School with respect to Graziani's assimilation of money to income. We will argue below that the issue at hand is a mere matter of definitions.

\section{Production and money creation: a causal relation}

As Parguez (2004) explains, firms need bank credit in order for net wealth or capital to be accumulated through the production of consumption goods and services. Along this line, Graziani (1994) remarkably noticed that banks carry out payments 'without having at their disposal any previous deposits' (Cencini, 1997, p. 274). Indeed, when they fulfil firms' financial needs, banks advance liquidity without disposing of any previous income; hence, 'initial finance' has to cover the whole cost of producing consumer and investment goods (Graziani, 2003, p. 69). As observed by Lavoie (2004, p. 136), Graziani (1984) 'made the point that the finance motive applied to all production, and not just investment expenditures'. The creation of bank money is thus instrumental in order for firms to carry out their wage payments. Thus, money is a means to express the value of newly produced output numerically. If so, then money and labour have no value: it is the payment of wages that instantaneously determines the creation of the economic (net) value of production, that is, wage goods as well as capital goods. This conclusion, shared by the circuitists, goes far beyond the traditional objective of monetary theory, which 'has been to explain the value of money, that is, the quantity of goods purchasable with a unit of money' (Tobin and Golub, 1998, p. 57).

Further, according to the MTP, economic growth is influenced by bank credit to firms and by the decisions of capitalists' (or shareholders') regarding consumption and investment goods: as Graziani (2003, p. 24) puts it by quoting Kregel (1973), in line with the so-called KeynesKalecki formulation, "firms can decide the activity levels and the nature of production [...] while wage earners $[\ldots]$ can only buy real consumer goods in the amount made available by producers'. According to this view, granted firms' independence concerning production plans, 'money is created not by the bank but by the agents themselves, the moment they decide to consider the bank as the ruler of their mutual payments' (Schmitt, 1984, cited in Graziani, 2003, p. 65). Further, as explained by Graziani $(1994,2003)$, the creation of bank money is instantaneous, as a result of the granting of a bank loan to some firms. Therefore, production and money creation are intimately correlated, money being ultimately created by production: in a monetary economy of production, a causal relation between physical production and money creation is indeed observed, the former being the cause and the latter the effect.

In other words, a monetary circuit consists in money creation and destruction. As explained by Smithin (1994, p. 173), according to Graziani (1989) 'money is created when loans are extended, and is destroyed, via the "law of reflux", when loans are repaid'. When a bank credit is granted to firms in order to finance production activities - paraphrasing Graziani - loans are created and used to pay wages to workers: as Lavoie (2003, p. 507) puts it, '[1]oans are created ex nihilo [...] by punching a key on the computer, as long as the borrower is credit-worthy'. Money would then be destroyed when it is spent in the purchase of production. It must be ob- 
served therefore that a certain period of chronological time could elapse between the moment when money is created and the moment when money is destroyed. According to Parguez (2004, p. 257, our italics), in such a version of the monetary circuit, assuming that no bank loans are extended to workers, 'money creation is identical to the wage bill. ${ }^{2}$ This association of money to the wages paid to workers gives rise to bank deposits; before their destruction, a certain level of investment takes place. What matters here is that at the end of the monetary circuit bank money is completely destroyed. According to Graziani, indeed, money creation occurs when an agent borrows from a bank, money being destroyed when a credit is repaid to the bank:

[a] complete theoretical analysis has to explain the whole itinerary followed by money, starting with the moment credit is granted, going through the circulation of money in the market, and reaching the final repayment of the initial bank loan. Money being created by the banking sector and being extinguished when it goes back to the same sector, its existence and operation can be described as a circuit (Graziani, 2003, pp. 25-26).

Now, other circuit theorists, particularly those belonging to the so-called Dijon School (see Schmitt, 1984; Cencini, 1997, 2001), identify the association of money and output with the formation of income, namely the creation of an economic value that has both a real and a nominal dimension. ${ }^{3}$ The issue at hand was debated for instance by Cencini (1985a, 1985b) and Graziani (1985) in a series of three articles published in Studi Economici.

Before investigating this issue in depth, let us point out a methodological difference in the approaches adopted by the theories of the monetary circuit (the Dijon School on the one hand, and the Italian and Anglo-Saxon Schools on the other hand) as far as monetary flows and stocks are concerned (Schmitt, 1982, and Tortorella Esposito, 2012, elaborate on this point). As a matter of fact, the Dijon School is known for having developed a theory of money emissions according to which income is a monetary stock (the overall amount of bank deposits that are created as a result of a production process), 'the result of a constantly renewed process of creation involving money and production of goods and services' (Rochon and Rossi, 2003, pp. xxxviixxxviii). On the contrary, other circuitist traditions (namely the Italian and the Anglo-Saxon versions of circuit theory) consider income as a flow of expenditure over time. The difference between the French tradition and the Italian tradition is indeed remarkable. By referring to double-entry bookkeeping, the Dijon School argues that (real and monetary) income is created and destroyed in two different instants of time. What exists meanwhile, that is, between the moment it is created and the moment it is destroyed, is a bank deposit, to wit, the monetary form of real goods produced. The Italian and Anglo-Saxon Schools assert by contrast that income is to be studied within a dynamic framework - according to a conception of time that is either continuous or discontinuous. The latter approach, according to which income is a function of time, is firmly rejected by the Dijon School and replaced by the so-called 'quantum theory of production' (see Cencini and Rossi, 2015).

The authors of the Dijon School argue that money, which originates when a bank grants a credit line to firms, is also destroyed at the very instant of its creation, and not, as is often thought, when the bank credit is repaid to its originator. Money, according to this view, is credit and debit at the same time: a credit and a debit of firms and of banks in a twofold, instantaneous relation. What exists meanwhile, that is, between the granting of credit and its extinction, is income in the form of bank deposits. 'Between the moment it is created (through the payment of the factors of production) and the moment it is destroyed, income is saved [...] in the form of a bank deposit. [...] Like money, income only exists within the banking system in the form of a double entry relating two equivalent deposits of the opposite sign' (Cencini, 1997, pp. 274275). The Dijon School makes thereby a distinction between bank money and bank deposits essentially: bank money carries out payments, while bank deposits finance them (Rossi, 2007). Now, Graziani (1985, cited in Cencini, 1985b, p. 145) argued that such a use of the terms 'money' and 'income' is due to a 'strict division of society into classes' presumably operated by the

\footnotetext{
${ }^{2}$ We will briefly discuss this assumption in section 4 .

${ }^{3}$ This definition is controversial. See Lavoie (2003, p. 509).
} 
theorists of the Dijon School and properly opposed by him. However, this is not the case actually: given that human labour "is the only "factor of production", wages define the totality of income created by society. This solution [...] is not based, as claimed by Graziani, on the "strict division of society into classes" but on the evidence that only human labour is productive" (Cencini, 1985b, p. 145, our italics and our translation).

Nevertheless, as shown by both Graziani and the Dijon School, bank deposits are destroyed after investment activities are carried out or after income is distributed to households in several manners and finally spent in the consumption of wage goods. 'Following Graziani [...] the real supply of consumer goods made available to the working class as a whole ("wage goods") depends on the autonomous decisions of the firms' sector, that is of all industrial capitalists grouped together' (Bellofiore, 2004, p. 103). The hypothesis introduced by some circuitists, Graziani included, is that the entire income of wage earners is spent on purchasing wage goods: they introduce, in fact, the hypothesis of 'a zero workers' saving rate' (Parguez, 2004, pp. 257258). In this case, following Forges Davanzati and Realfonzo (2004, p. 66), 'firms get back all of the money they laid out to pay wages and so can pay off their debt to the banks (except for interest). If workers' propensity to consume is less than one, firms try to recuperate the unspent money by selling securities in the financial market' (see Carrera, 2014 on this point). According to Graziani's analysis, after receiving the proceeds of sales, firms extinguish their debts to banks, and these results in the destruction of money (Parguez, 2004, p. 257). However, it should be noted that the monetary circuit comes full circle only when the accumulation of capital has been completed: 'money is not fully destroyed before firms realize their desired accumulation' (Parguez, 2004, p. 261).

Accordingly, given a certain physical production, money creation is the first step in the formation of bank deposits, representing the supply and demand for those wage goods that are purchased by income earners, but also for those profits or capital goods that are produced in order to generate more values-in-use for society as a whole. Let us elaborate on this in the next section.

\section{Saving and profit: new insights}

The formation of income is a necessary condition for the formation of profit, and thereby also for the capacity of firms to achieve their investment goals. As Arena and Salvadori (2004) remind us, Graziani (1989, 1994, 2003), among others, argued that the entrepreneurs' aim is to earn a profit according to their investment (and shareholders' remuneration) plans. As Parguez (2004, p. 268) puts it, '[m]oney [...] is created and destroyed to provide firms with the profits they need to fulfil their accumulation plans endorsed by banks'. Following this line of reasoning, Graziani (2003, p. 103) argues that ' $[\mathrm{t}] \mathrm{he}$ level of profits depends directly on the level of [...] prices. As Bernard Schmitt [...] would say: "profits are born in the commodities market" (Schmitt 1984, chapter 4, pp. 134-5).' This amounts to arguing that profits closely depend on the level of (i) the selling price, and (ii) wages paid to workers in exchange for the production of consumption goods, being wages the sole macroeconomic cost of production.

As Godley (2004, p. 127) puts it, 'there is a gap in (historical) time between production and sales which generates a systemic need for finance'. Further, in our monetary economies of production, profits constitute the income of firms, and their raison d'être, according to the theory of the monetary circuit, is precisely to finance the production of capital goods.

The study of the production process over different periods of chronological time is not new in economic theory. As Seccareccia (2004, p. 288) points out, Robertson, in 1926, assumed the expenditure of income to follow the formation of income: Robertson defined the saving $(S)$ of current period $t$ as the difference between the output $(Y)$ of the previous period and consumption (C) of the current period: $S_{t}=Y_{t-1}-C_{t}$. Now, as Robertson (1940, p. 65) puts it, 'a man is said to be saving if he spends on consumption less than his disposable income'. On the assumption that saving (or hoarding) is zero, output of period $t-1$ is necessarily equal to consumption of period $t$. Furthermore, following Schmitt (1972, p. 55), 'the Robertsonian analysis shows up as a special case of Keynes', where Keynes described the income of period $t$ as identical to saving plus consumption in the same period. Particularly, the introduction of a period of time between production and consumption (namely, the Robertsonian 'day') into the MTP is legitimate, since it 
does not stand in the way of the necessary equality between the production carried out in period $t$ and the expenditure of income when the product of period $t$ is purchased by wage earners. From this perspective, Robertson's identity may be interpreted according to Graziani's and other monetary circuit analyses. In fact, according to a multi-period version of monetary circuit theories, the macroeconomic saving available in period $t$ to produce capital goods corresponds to the entirety of profits, and depends on the level of consumption at time $t$, which in turn is determined by the levels of both output and prices in the previous period. Robertson's equation can be re-read accordingly. Hence, profits happen to be the financial source of investment in productive activities. As Graziani (2003, p. 149) puts it:

according to the circulation approach, not only are profits commonly present, but they are totally independent of the abilities or the performance of the entrepreneur. Profits are only due to the fact that the firms [...] are also able to acquire the share of real product satisfying their production and investment plans.

According to recent advances in the monetary theory of production, the value of capital is strictly related to the entrepreneurial goal: the economic process leading to the creation of the value of capital lies in the effective investment of profit in the production of capital goods (see for instance Carrera, 2014). As Godley (2004, p. 127) puts it, 'total real income must be considered to be divided into three parts - that received by entrepreneurs, that received by labour and that received by banks': in their role of entrepreneurs, companies receive income in the form of profit, and investment consists in the share of profit effectively invested in the production of capital goods, the remaining part of profit being distributed to shareholders as dividends and finally spent in the purchase of wage goods. ${ }^{4}$

Consequently, Graziani and other theorists of the monetary circuit are logically led to reject the Walrasian view of entrepreneurs combining different production services according to their relative prices and 'marginal productivity': '[r]ather, they borrow money in order to increase the amount of money they own, that is, in order to earn net monetary profits' (Arena and Salvadori, 2004, p. xiii). On the contrary, according to the TMC, 'wage-earners do not have access to bank credit' (Arena and Salvadori, 2004, pp. xiii-xiv), as the banks' intermediation is devoted only to the investment plans of firms. However, as Seccareccia (2012-13, p. 277) observes, since the early 1980s households have been granted massive access to bank credit in the United States and elsewhere, giving rise later on to the so-called subprime crisis:

[c]ommercial banks are now found at the center of one large profit-making transactions machine that largely denies their original role in the productive sphere. It is their new activities, together with all the associated perverse incentives that this transformation has created, that brought about the financial crisis.

Given that monetary disorders remain painfully unsolved, the lessons of monetary circuit theory - to which Graziani made such valuable contributions - could not be more timely and pertinent.

\section{Conclusion}

Graziani's main theoretical contribution to the TMC consists in a thorough investigation of the process of money creation and destruction. By developing the TMC, Graziani shed new light on the MTP that was first expounded by Keynes (1936). As Arestis (2004) puts it, central to Graziani's monetary theory is the access of producers to bank

\footnotetext{
${ }^{4}$ As Parguez (2004, p. 262) observed, investment activities give rise to the so-called 'Russian dolls theorem' of profits spelled out by the Dijon School (see Rossi, 2001, p. 163): '[p]rofits are hidden within the wage bill and both their existence and magnitude depend on the desired rate of exploitation reflected in the transfer price or macro-economic price'.
} 
credit according to their production plans. In this paper we have analysed Graziani's original contribution to the MTP in terms of (i) the rejection of the neoclassical dichotomy, (ii) the causal relationship between production and money creation, and (iii) the definition of macroeconomic saving.

Graziani is well aware that money, as created by banks, is merely a token, a numerical non-dimensional tool instrumental for the division of produced output between consumption and investment goods. The association between money and output as an identity is not new in economic theory, although it is often ignored. Money was paid special attention by Smith (1777 [1981]) with respect to commodities in general. Although Ricardo distanced himself from the conception of money as substance, a full rejection of money identified with any commodity can be traced back to Marx. Also, Graziani knew that, by conceiving money as a commodity, neoclassical theory fails to integrate money into the production process. And again, Graziani and other circuitists rejected the absence of profits in modern economies (a claim by neoclassical economists) and looked for a monetary theory alternative to general equilibrium theory; no explanation of price determination can in fact be found in the Walrasian theory of economic growth (Solow, 2000). Hence, Graziani and other circuitists developed the TMC based on Keynes's 1936 work, which led them to reject the dichotomy between real and nominal magnitudes, and to assert the existence of absolute prices versus the neoclassical determination of value in terms of relative prices.

As long as firms need bank loans to achieve their investment goals, credit lines are extended to companies and wages are paid out to workers. Further, as observed by Graziani $(1994,2003)$, the creation of bank money is instantaneous, an event triggered by the granting of a bank loan to firms. It is nevertheless arguable that the production of goods, that is, the real content of money, is the sine qua non condition for money to be created, this meaning that a causal relation does exist between production and money creation, the former being the cause and the latter the effect: labour is hence really the only 'factor of production' whose existence is prior to money creation. Further, once money is created, it will also be destroyed. What is crystal clear is that bank deposits are destroyed after capital goods are produced and wage goods completely sold to income earners: as Parguez (2004) puts it, the monetary circuit is closed once the accumulation of capital is completed.

According to Graziani and other circuitists, wage payments are a necessary condition for the formation of profit. Profits, in turn, depend on the level of transfer or macroeconomic price of wage goods. Corporate investment plans, in fact, can be implemented through the investment of profit in a new production of capital goods. Robertson's (1940) 'day' elapsing between the production of wage goods and their consumption helps understand the monetary analysis of production. Monetary circuit theory shows that capital value is equal to profits effectively invested in the production of capital goods. In addition, contrary to the TMC's assumption that wage earners do not have access to bank credit (see Arena and Salvadori, 2004), financial institutions have recently acted in total disregard of the lessons taught by the TMC (Seccareccia, 2012-13; Rossi, 2013, 2015). Monetary disorders have therefore considerably worsened across the global economy; witness the persistent financial instability and the systemic crisis that erupted in 2008 worldwide. These have not been properly addressed by mainstream economists; nor have they been cured by the changes in financial regulations promoted by these economists. Let us hope that this unsatisfactory state of affairs will induce researchers and policymakers to explore the theory of the monetary circuit that Augusto Graziani worked hard to build. It would be an appropriate way to honour and do justice to Graziani's scholarly work, and to pay tribute to his death on 5 January 2014. 


\section{Bibliography}

Arena, Rirchard; Salvadori, Neri (eds.). 2004. Money, Credit and the Role of the State: Essays in Honour of Augusto Graziani. Farnham and Burlington, Ashgate.

Arestis, Philip. 2004. Financial sector reforms in developing countries with special reference to Egypt. In Arena, Rirchard; Salvadori, Neri (eds.), Money, Credit and the Role of the State: Essays in Honour of Augusto Graziani, Farnham and Burlington, Ashgate, pp. 373-392.

Bellofiore, Riccardo. 2004. As if its body were by love possessed. Abstract labour and the monetary circuit: a macro-social reading of Marx's labour theory of value. In Arena, Rirchard; Salvadori, Neri (eds.), Money, Credit and the Role of the State: Essays in Honour of Augusto Graziani, Farnham and Burlington, Ashgate, pp. 89-114.

Carrera, Andrea. 2014. Studies in profit and capital formation: an alternative theory of distribution, Cuadernos de Economía - Spanish Journal of Economics and Finance, 38 (106), pp. 110.

Cencini, Alvaro. 1985a. Moneta e produzione, Studi Economici, 25, pp. 105-129.

- 1985b. Replica al commento di Augusto Graziani, Studi Economici, 25, pp. 143-149.

- 1997. Book's review of A. Graziani's 'The Monetary Theory of Production', Structural Change and Economic Dynamics, 2, pp. 272-277.

- 2001. Monetary Macroeconomics: A New Approach. London and New York, Routledge.

Cencini, Alvaro; Rossi, Sergio. 2015. Economic and Financial Crises: A New Macroeconomic Analysis, Basingstoke, UK and New York, Palgrave Macmillan.

Davidson, Paul. 2003-2004. Setting the record straight on "A history of post Keynesian economics", Journal of Post Keynesian Economics, 26, pp. 245-272.

Deleplace, Ghislain; Nell, Edward J. 1996. Introduction: monetary circulation and effective demand In Deleplace, Ghislain; Nell, Edward J. (eds.), Money in Motion: The PostKeynesian and Circulation Approaches, London and New York, Macmillan and St. Martin's Press, pp. 3-41.

Fontana, Giuseppe; Realfonzo, Riccardo (eds.). 2005. The Monetary Theory of Production: Tradition and Perspectives, Basingstoke and New York, Palgrave Macmillan.

Forges Davanzati, Guglielmo; Realfonzo, Riccardo. 2004. Labour market deregulation and unemployment in a monetary economy. In Arena, Richard; Salvadori, Neri (eds.), Money, Credit and the Role of the State: Essays in Honour of Augusto Graziani, Farnham and Burlington, Ashgate, pp. 65-74.

Garegnani, Pierangelo. 1979. Valore e domanda effettiva: Keynes, la ripresa dell'economia classica e la critica ai marginalisti. Torino, Einaudi.

Godley, Wynne. 2004. Weaving cloth from Graziani's thread: endogenous money in a simple (but complete) Keynesian model. In Arena, Richard. Salvadori, Neri (eds.), Money, Credit and the Role of the State: Essays in Honour of Augusto Graziani, Farnham and Burlington, Ashgate, pp. 127-135.

Graziani, Augusto. 1983. Moneta senza crisi, Materiali Filosofici, 7, pp. 95-112.

- 1984. The debate on Keynes's finance motive, Economic Notes, 1, pp. 5-33.

- 1985. Commento ad Alvaro Cencini, Studi Economici, 25, pp. 130-142.

- 1989. The theory of the monetary circuit, Thames Papers in Political Economy, Spring.

- 1994. La teoria monetaria della produzione. Arezzo, Banca Popolare dell'Etruria e del Lazio.

- 1996. 'Money as purchasing power and money as a stock of wealth in Keynesian economic thought', in Deleplace, Ghislain; Nell, Edward J. (eds.), Money in Motion: The PostKeynesian and Circulation Approaches, London and New York, Macmillan and St. Martin's Press, pp. 139-154.

- 2003. The Monetary Theory of Production, Cambridge, Cambridge University Press.

Hicks, John R. 1937. Mr. Keynes and the Classics: a suggested interpretation, Econometrica, 5, pp. 147-159.

- 1967. Monetary theory and history - an attempt at perspective. In Critical Essays in Monetary Theory, Oxford, Clarendon Press, pp. 155-173. 
- 1982. The credit economy. In Money, Interest and Wages: Collected Essays in Economic Theory, Oxford, Basil Blackwell, vol. 2, pp. 266-275.

- 1989. A Market Theory of Money, Oxford, Oxford University Press.

Keynes, John M. 1930 [1988]. A Treatise on Money, London and New York, Macmillan and St Martin's Press.

— 1933 [1973]. A monetary theory of production. In Keynes, John M., The Collected Writings of J.M. Keynes, London, Macmillan, vol. XIII, pp. 408-411.

- 1936. The General Theory of Employment, Interest and Money. London, Macmillan.

Kregel, Jan A. 1973. The Reconstruction of Political Economy: An Introduction to PostKeynesian Economics. London, Macmillan.

Lavoie, Marc. 2003. A primer on endogenous credit-money. In Rochon, Louis-Philippe; Rossi, Sergio (eds.), Modern Theories of Money: The Nature and Role of Money in Capitalist Economies, Cheltenham and Northampton, Edward Elgar, pp. 506-543.

- 2004. Circuit and coherent stock-flow accounting. In Arena, Richard; Salvadori, Neri (eds.), Money, Credit and the Role of the State: Essays in Honour of Augusto Graziani, Farnham and Burlington, Ashgate, pp. 136-151.

Lunghini, Giorgio. 1988. Equilibrio. Torino, Boringhieri.

Modigliani, Franco. 1944. Liquidity preference and the theory of interest and money, Econometrica, 12, pp. 45-88.

Moggridge, Donald E. 1992. Maynard Keynes: An Economist's Biography. London and New York, Routledge.

Moore, Basil J. 2004. Saving and investment: Keynes revisited. In Arena, Richard; Salvadori, Neri (eds.), Money, Credit and the Role of the State: Essays in Honour of Augusto Graziani, Farnham and Burlington, Ashgate, pp. 239-256.

Parguez, Alain. 1975. Monnaie et macroéeconomie. Paris, Economica.

- 1996. Beyond scarcity: a reappraisal of the theory of the monetary circuit. In Deleplace, Ghislain; Nell, Edward J. (eds.), Money in Motion: The Post Keynesian and Circulation Approaches, London and New York, Macmillan and St Martin's Press, pp. 155-199.

-2001. Money without scarcity: from the horizontalist revolution to the theory of the monetary circuit. In Rochon, Louis-Philippe; Vernengo, Matias (eds.), Credit, Interest Rates and the Open Economy, Cheltenham and Northampton, Edward Elgar, pp. 69-103.

- 2004. The solution of the paradox of profits. In Arena, Richard; Salvadori, Neri (eds.), Money, Credit and the Role of the State: Essays in Honour of Augusto Graziani, Farnham and Burlington, Ashgate, pp. 257-270.

Pasinetti, Luigi L. 1986. Dal Treatise on Money alla General Theory: continuità o rottura?. In Kregel, Jan. (ed.): Nuove interpretazioni dell'analisi monetaria di Keynes, Bologna, Il Mulino, pp. 43-51.

- 1989. Aspetti controversi della teoria del valore. Bologna, Il Mulino.

- 2007. Keynes and the Cambridge Keynesians: A Revolution in Economics To Be Accomplished. Cambridge, Cambridge University Press.

Robertson, Dennis H. 1940. Essays in Monetary Theory. London, P.S. King and Son.

Rochon, Louis-Philippe; Rossi, Sergio. 2003. Introduction. In Rochon, Louis-Philippe; Rossi, Sergio (eds.), Modern Theories of Money: The Nature and Role of Money in Capitalist Economies, Cheltenham, UK, Northampton, MA, USA, Edward Elgar, pp. xx-lvi.

- 2013. Endogenous money: the evolutionary versus revolutionary views, Review of Keynesian Economics, 1, pp. 210-229.

Rossi, Sergio. 2001. Money and Inflation: A New Macroeconomic Analysis. Cheltenham and Northampton, Edward Elgar.

- 2007. Money and Payments in Theory and Practice. London and New York, Routledge.

- 2013. 'Money, banks, and payments: the structural factors of financial instability and systemic crises. In Ülgen, Faruk (ed.): New Contributions to Monetary Analysis: The Foundations of an Alternative Economic Paradigm, Abingdon, UK and New York, Routledge, pp. 188-204.

- 2015. Structural reforms in payment systems to avoid another systemic crisis, Review of Keynesian Economics, 3, pp. 213-225. 
Schmitt, Bernard. 1972. Macroeconomic Theory: A Fundamental Revision. Albeuve, Castella.

- 1975. Théorie unitaire de la monnaie, nationale et internationale. Albeuve, Castella.

- 1982. Time as quantum. In Baranzini, Mauro (ed.): Advances in Economic Theory, Oxford, Basil Blackwell, pp. 115-125.

- 1984. Inflation, chômage et malformations du capital. Paris and Albeuve, Economica and Castella.

Seccareccia, Mario. 2004. 'Aspects of a new conceptual integration of Keynes's Treatise on Money and the General Theory: logical time units and macroeconomic price formation. In Arena, Richard; Salvadori, Neri (eds.). Money, Credit and the Role of the State: Essays in Honour of Augusto Graziani, Farnham and Burlington, Ashgate, pp. 285-310.

- 2012-13. Financialization and the transformation of commercial banking: understanding the recent Canadian experience before and during the international financial crisis, Journal of Post Keynesian Economics, 35, pp. 277-300.

Smith, Adam. 1777 [1981]. An Inquiry into the Nature and Causes of the Wealth of Nations, edited by Roy H. Campbell and Andrew S. Skinner, Indianapolis, Liberty Fund, 2 vols.

Smithin, John. 1994. Controversies in Monetary Economics: Ideas, Issues and Policy. Aldershot and Brookfield, Edward Elgar.

- 2013. Keynes's theories of money and banking in the Treatise and The General Theory, Review of Keynesian Economics, 1, pp. 242-256.

Solow, Robert M. 2000. The neoclassical theory of growth and distribution, Banca Nazionale del Lavoro Quarterly Review, 53, pp. 349-381.

Sraffa, Piero; Dobb Maurice H. (eds.). 1971-1980. The Works and Correspondence of David Ricardo, Cambridge, Cambridge University Press, 11 vols,.

Sylos Labini, Paolo. 1948. 'Saggio dell'interesse e reddito sociale', Rome, Accademia Nazionale dei Lincei, Rendiconti, Series VIII, vol. 3, nos. 11-12.

— 2005. Franco Modigliani and oligopoly, Banca Nazionale del Lavoro Quarterly Review, 58, pp. 41-48.

Tobin, James; Golub, Stephen S. 1998. Money, Credit, and Capital. Boston, Irwin/McGrawHill.

Tortorella Esposito, Guido. 2012. La letteratura post-Keynesiana. "Scuola di pensiero" o "tradizione di ricerca”? Bergamo, Sestante Editore. 